\title{
Wood Industry Trade Competitiveness of Selected Countries of Southeast Europe
}

\section{Trgovinska konkurentnost drvne industrije u zemljama jugoistočne Europe}

\author{
Original scientific paper • Izvorni znanstveni rad \\ Received-prispjelo: 12. 2. 2018. \\ Accepted-prihvaćeno: 4. 7. 2019. \\ UDK: $630 * 74 ; 630 * 836.1 ; 630 * 892.42$ \\ https://doi.org/10.5552/drvind.2019.1803
}

\begin{abstract}
The paper examines the trade competitiveness of the wood industry as a whole and some of its parts (Cork and wood, Cork and wood manufactures and Furniture and parts) of five countries of South Eastern Europe (Serbia, Croatia, Bulgaria, Romania and Bosnia \& Herzegovina) by using six indicators (Revealed Comparative Advantage - RCA, Index of Trade Performance - RCA2, Competitiveness Growth Index - RCA1, Michaely Index - MI, Index of Contribution to the Trade Balance - CTB and Grubel-Lloyd Index - GLI) in the period 2000-2015. On the basis of the results obtained, it was concluded that the wood industry of these countries observed as a whole has great export potential and that it significantly participates in their processing industry. The results of the survey show that companies from the wood industry viewed as a whole are competitive on the domestic market. However, this cannot be said of the international competitiveness of the timber industry of these countries. To be specific, the production of cork and wood from Bulgaria and Serbia, cork and wood manufactures excluding furniture from Bulgaria, Serbia and Croatia, as well as furniture and parts manufacturers from Bulgaria do not have a competitive advantage in the international market. By combining the values of six competitiveness indicators, it can be concluded that there is a statistically significant difference in the competitiveness of the wood industry of the countries observed. It can also be concluded that the degree of wood processing has a positive impact on their export competitiveness, this impact not being statistically significant, and that the level of finalization of production did not have a positive impact on the competitiveness of the wood industry of the selected countries of Southeastern Europe.
\end{abstract}

Keywords: trade competitiveness, trade competitiveness indicators, wood industry, Southeast Europe

SAŽETAK・U radu se istražuje trgovinska konkurentnost drvne industrije pet zemalja jugoistočne Europe (Srbije, Hrvatske, Bugarske, Rumunjske te Bosne i Hercegovine), i to u cjelini i po dijelovima (pluto $i$ drvo, proizvodi od pluta i drva, namještaj i dijelovi za namještaj). Istraživanje je provedeno u razdoblju od 2000. do 2015. uz pomoć šest pokazatelja konkurentnosti (utvrđene komparativne prednosti-RCA, indeksa neto poslovanja-RCA2,

\footnotetext{
${ }^{1}$ Author is professor at the Faculty of Economics, University of Niš, Niš, Serbia. ${ }^{2}$ Author is researcher at the Institute of Economic Sciences, Belgrade, Serbia, and professor in the College of Textile Design, Technology and Management, Belgrade, Serbia. ${ }^{3}$ Author works is employed in the Interalum, Ljubljana, Slovenia.

${ }^{1}$ Autor je profesor Sveučilišta u Nišu, Ekonomski fakultet, Niš, Srbija. ${ }^{2}$ Autor je istraživač Instituta ekonomskih znanosti, Beograd, Srbija i profesor Visoke tekstilne strukovne škole za dizajn, tehnologiju i menadžment, Beograd, Srbija. ${ }^{3}$ Autor je zaposlen u tvrtki Interalum, Ljubljana, Slovenija.
} 
indeksa rasta konkurentnosti - RCA1, Michaely indeksa - MI, indeksa doprinosa trgovinskoj bilanci - CTB $i$ Grubel-Lloyd indeksa-GLI). Iz dobivenih je rezultata zaključeno da drvna industrija navedenih zemalja, promatrana u cjelini, ima velik izvozni potencijal i da značajno sudjeluje u njihovoj prerađivačkoj industriji. Rezultati istraživanja pokazuju da su poduzeća iz sektora drvne industrije, promatrana u cjelini, konkurentna na domaćem tržištu. Međutim, to se ne može reći i za međunarodnu konkurentnost drvne industrije tih zemalja. Konkretno, proizvodnja pluta i drva iz Bugarske i Srbije, proizvodi od pluta i drva iz Bugarske, Srbije i Hrvatske, kao i namještaj i dijelovi za namještaj iz Bugarske nemaju konkurentsku prednost na međunarodnom tržištu. Kombiniranjem vrijednosti šest pokazatelja konkurentnosti utvrđena je statistički značajna razlika u konkurentnosti drvne industrije promatranih zemalja. Također se može zaključiti da stupanj obrade drva ima pozitivan utjecaj na njihovu izvoznu konkurentnost, ali taj utjecaj ipak nije statistički značajan. Nadalje, uočeno je da stupanj finalizacije proizvodnje nije pozitivno utjecao na konkurentnost drvne industrije promatranih zemalja jugoistočne Europe.

Ključne riječi: trgovinska konkurentnost, pokazatelji trgovinske konkurentnosti, drvna industrija, jugoistočna Europa

\section{INTRODUCTION}

\section{UVOD}

Competitiveness is one of the most powerful concepts of modern economic thought (Garelli, 2004). However, given the complexity of competitiveness, there is no generally accepted definition of this phenomenon. Broader concept of competitiveness relates to tendency and skill to compete, ability to win and retain market position, and to increase market share and profitability. In other words, the term implies business success.

The concept of competitiveness is the result of a long history of economic thought, which gave rise to various aspects of this complex phenomenon. Apart from company level, competitiveness is increasingly popular at the national level, at the regional level, and at the industry level, as well as between individual sectors (Cvetanović et al., 2015).

The paper examines wood industry trade competitiveness in five countries of Southeast Europe (Serbia, Croatia, Romania, Bulgaria, and Bosnia \& Herzegovina) and its subsectors (cork and wood, cork and wood manufactures excluding furniture, and furniture and parts) in the period 2000-2015. Wood industry is one of the sectors where national economies can influence the market of Southeast Europe, and to a lesser extent the European market, by using their own resources.

Wood-based production in all five countries involved has a long tradition, having a sufficient amount of high-quality wood raw material that is naturally renewable and closely related to various sectors of the national economy. It contributes to economic, ecological, and social development of the countries and regions, where wood is used as a renewable resource. Wood-based products are biodegradable and can be used as substitutes for materials arising from non-renewable sources.

The need to study wood industry is partly the result of the fact that the European Union is focusing on economic development based on renewable sources. Wood industry is certainly a promising sector, and the EU encourages its development, wishing it to be a highly competitive activity on the world market. Three countries to be analyzed are full members of the EU
(Croatia, Romania, and Bulgaria), Serbia is in the accession phase, while Bosnia \& Herzegovina is a signatory to the EU Accession Treaty.

The following hypotheses are set.

H1: Wood industry of the selected countries as a whole and considering its parts is competitive on the domestic and foreign markets;

$\mathrm{H} 2$ : There is a significant difference in the achieved level of trade competitiveness of wood industry in these countries;

H3: Level of trade competitiveness of wood industry in these countries is related to production finalization stage.

Wood industry competitiveness is here seen as the ability of domestic companies to sell products on the domestic and international markets in a competitive struggle with companies from other economies in the same area, through efficient use of production factors. Competitiveness indicators used in the paper are: Revealed Comparative Advantage - RCA, Index of Trade Performance - RCA2, Competitiveness Growth Index - RCA1, Michaely Index - MI, Index of Contribution to the Trade Balance - CTB, and Grubel-Lloyd Index - GLI.

The appropriate statistical methods are used to analyze wood industry competitiveness and its parts in five countries covered. The obtained results are then mutually compared.

\section{MATERIALS AND METHODS \\ 2. MATERIJALI I METODE}

\subsection{Concept of industry trade competitiveness} 2.1. Koncept trgovinske konkurentnosti

Competitiveness is a dynamic, multifactorial, and hierarchical phenomenon that encompasses individual companies, company clusters, all companies in a particular sector, and, finally, all companies and sectors in a given country (Jovović, 2017). The past two decades have been abundant in reports, indices, as well as academic and policy debates dealing with national and industry competitiveness and related performance issues. This shows that governments are more and more focusing on their country's competitiveness and grasping its structural drivers. Consequently, all economies, notwithstanding their level of development, 
struggle to uplift their competitiveness, particularly their manufacturing industry competitiveness, to ultimately raise their country's well-being (Fagerberg et al., 2007; UNIDO, 2013).

Since the 1990s, most economists and experts have found that competitiveness has the status of a "natural law of market economy" (Kitson et al., 2004). However, since competitiveness does not have a single meaning, it can be analyzed in different ways, i.e. depending on the chosen concept, it can be used with different methodologies and indicators. Also, there are some differences in researching the competitiveness of companies, industries, and countries. In this regard, various institutions monitor the competitiveness of countries using micro and macro competitiveness indicators. The most prominent indicators of competitiveness at the national level are the World Competitiveness Index of the Institute for Management Development - IMD, Global Competitiveness Index of the World Economic Forum, and UNIDO Competitive Industrial Performance Index. Unlike company level, where competitiveness is fundamentally seen as the capacity "to maximize productivity and factor incomes (wages and profits) on a sustained basis" (Hatzichronoglou, 1996), and where foreign trade indicators are used to record companies' individual and overall competitiveness (UNIDO, 2013), the study of competitiveness at the industry level gives some insight into the impact of economic policy on the economy, with data more accessible and internationally more comparable than data at the company level (Toming, 2007).

When it comes to measuring industry competitiveness, productivity and exports are the commonly analyzed variables. Another indicator of industry competitiveness lies in relative prices in that industry, seen in relation to one or more foreign competitors (Siggel, 2006).

Industry competitiveness refers to the country's industry ability to generate profit in relation to identical industries in other countries, the ability to attract production factors in relation to other industries within the same country or in other countries, and the ability to adapt the industry to socio-economic conditions. Therefore, coordination between companies in a particular field and certain socio-economic conditions in which they operate justifies the analysis of competitiveness at the industry level.

UNIDO $(2002,2013)$ sees industry competitiveness as "the capacity of countries to increase their presence in international and domestic markets whilst developing industrial sectors and activities with higher value added and technological content", pointing to main elements of industry competitiveness - ability to produce and export competitively, technological growth and progress, and, ultimately, impact on worldscale manufacturing industry and exports (UNIDO, 2013). Referring to this approach, Lall (2001) believes that "competitiveness in industrial activities means developing relative efficiency along with sustainable growth", indicating that the rise in industry competitiveness requires abandoning static sources of cost ad- vantage and focusing on diverse industrial activities (climbing the technological ladder). This idea of industry competitiveness is multidimensional by nature, and may be relevant both in 'ex-ante' and 'ex-post' analyses, depending on whether the focus is on 'process assessment' or 'outcome assessment' of co55522 country industry competitiveness. In particular, this perspective may involve both a specific set of 'structural drivers' of industry competitiveness (i.e. process) and the resulting competitive industry performance of nations (i.e. outcome). Industry competitiveness is measured based on perceptible realities. What is more, the idea maintains a 'stochastic' nature, visualizing the possibility of pluralistic industry patterns of progress (UNIDO, 2013).

Although being a subject of various studies, there is no universally valid and generally accepted definition of industry competitiveness in literature. In the case of sectoral competitiveness, it involves macroeconomic assessment of competitiveness of certain sectors, so the analysis of industry competitiveness as a whole overlaps with individual sectors.

Rybakovas (2009) points out that industry competitiveness or sectoral competitiveness depends on the quality of products and services, customer satisfaction, effectiveness of internal processes, innovation, employee satisfaction, etc. It is important to note that most research on industry competitiveness makes no distinction between domestic and international markets, because they believe that, due to trade liberalization, companies are exposed to global competition. However, although this starting point is largely accurate, it still cannot be said that there is a completely unified global market, either in the formal sense (e.g., the existence of various non-tariff barriers), nor in the essential sense (e.g. there is still a need for local adjustment to the requirements and needs of consumers, because the needs and demands of consumers are still far from universal and much more time will pass while consumers' taste and needs become homogenized globally).

A clear and logical basis for measuring competitiveness can be the balance of external trade, as it relies on the analysis of industry comparative advantage. At the sector level, international trade is also taken into account. Sector competitiveness, on the one hand, relates to the company ability to compete on domestic and foreign markets. On the other hand, it is a country ability to support business development because competitiveness is the key determinant of growth, maintenance, and creation of jobs in every economy.

\subsection{Indicators of industry and sector trade competitiveness}

2.2. Pokazatelji trgovinske konkurentnosti industrije i industrijskih sektora

In this paper, research relies on secondary sources, scientific studies dealing with theoretical and empirical analysis of sector and country trade competitiveness, and foreign trade statistics on wood industry.

The current research on competitiveness is based on the use of statistical methods to assess the detected and expected comparative and competitive advantage. 
In fact, there is not a single comprehensive indicator of competitiveness, regardless of whether the study focus is on economy competitiveness as a whole or its parts. Some indicators relate only to the economy as a whole, while others can show both competitiveness at the level of the economy as a whole, and competitiveness at lower levels of economic structure. In practice, a number of indicators for the detection and measurement of competitiveness have been developed and used, and they represent a specific combination of competitiveness characteristics of the selected industry sector and/or countries (Han et al., 2009; Dieter and Englert, 2007).

Competitiveness indicators can be classified into two basic groups: result-oriented indicators and determinant-oriented indicators of competitiveness (Dieter and Englert, 2007). Result-oriented indicators help to reveal an ex-post competitive position. They are used to determine competitiveness at the sector level and on the international market. Based on the study of literature and methodologies of international organizations that measure competitiveness at the economy and industry levels, it has been concluded that more indicators are used to assess competitiveness of individual industries and their internal structures.

In reference (or related) works in this field (Sujová and Hlaváčková 2015; Sujová et al., 2015a,b), the most frequently used trade competitiveness indicators were:

a) Revealed Comparative Advantage - RCA. There are several variants of this indicator: RCA indicator measures competitiveness at the national level, and is obtained as the logarithm of export and import ratio of the commodity group in total export and import of the observed country. This indicator can be adjusted to reveal competitiveness of commodity groups in the economy, or to determine cross-sectoral competitiveness. Competitiveness Growth Index - RCA1 allows determining economy competitiveness on the regional and global market. It is obtained by comparing the share of certain commodity group export in the total country export in relation to the value of total exports of the observed commodity group and the total global value of exports. Index of Net Business Performance - RCA2 (Balassa, 1965) measures the share of a particular sector in active trade balance. It is obtained as a percentage difference between exports and imports of commodity groups and the sum of exports and imports of these commodity groups.

RCA index of inter-sectoral specialization (in line with the methodology of the United Nations Conference on Trade and Development - UNCTAD, International Trade Center - ITC, World Bank and World Trade Organization - WTO) analyzes the difference between net exports, existing specialization, trade deficit, and theoretical net exports.

b) Michaely Index (Michaely, 1962) shows the degree of country specialization in a commodity group or branch. It measures the share of the commodity group in total national exports.

c) Index of Contribution to the Trade Balance CTB (Melišek, 2012) measures the contribution of cer- tain sectors to the national trade balance. It is obtained as a difference between the actual and expected balance of the economy.

d) Grubel-Lloyd Index - GLI analyzes the share of goods with inter-sectoral character in foreign trade. Higher share points to a higher level of national competitiveness. GLI measures country capacity to exploit economies of scale (Grubel and Lloyd, 1971).

The actual competitiveness of the wood industry as well as its parts is examined in this paper by using the above-mentioned methods, based on the example of five countries of Southeast Europe (Serbia, Croatia, Romania, Bulgaria, and Bosnia \& Herzegovina) in the period 2000-2015.

Indicators used in reference research have been modified and their calculation has been customized to provide inter-sectoral competitiveness analysis. In relation to their use, abbreviations are used as follows: $e_{\mathrm{sc}}-$ value of exports of commodity group " $\mathrm{s}$ " in sector "s" and country "c",

$i_{\text {sc }}$ - value of imports of commodity group "s" in sector "s" and country "c",

$E_{\text {sc }}$ - value of exports of sector "s" and country "c", $I_{\mathrm{sc}}$ - value of imports of sector "s" and country "c", $E_{\mathrm{c}}$ - value of total exports from country "c",

$I_{\mathrm{c}}$ - value of total imports into country "c",

$E_{\mathrm{s}}-$ global (world) export of commodity group "s", $E$ - total global (world) exports

RCA represents a comparative advantage or lack of export and its competitive ability. It is calculated at two levels, national (N-RCA) and sectoral (S-RCA):

$$
\begin{gathered}
N-R C A=\ln \frac{\frac{e_{\mathrm{sc}}}{i_{\mathrm{sc}}}}{\frac{E_{\mathrm{c}}}{I_{\mathrm{c}}}} \\
S-R C A=\ln \frac{\frac{e_{\mathrm{sc}}}{i_{\mathrm{sc}}}}{\frac{E_{\mathrm{sc}}}{I_{\mathrm{sc}}}}
\end{gathered}
$$

$\mathrm{RCA}<0$ indicates comparative disadvantage of products. On the contrary, RCA $>0$ implies the existence of a certain comparative advantage in the product export or sector to which the product belongs. Finally, RCA $>1$ indicates that the product and industry are internationally competitive.

RCA1 is calculated as follows:

$$
R C A 1=\frac{\frac{e_{\mathrm{sc}}}{E_{\mathrm{c}}}}{\frac{e_{\mathrm{s}}}{E}}
$$

RCA1 $>1$ points to comparative advantage of industries on the global market, while RCA $1<1$ means that the product group has no competitive ability on the relevant market.

RCA2 measures the comparative advantage of industry or product export and its competitive ability. It is calculated by using the formula:

$$
R C A 2=\frac{e_{\mathrm{sc}}-i_{\mathrm{sc}}}{e_{\mathrm{sc}}+i_{\mathrm{sc}}}
$$


For RCA2 variables, the following applies: when RCA2 $=-1$, export does not exist and then $\mathrm{e}_{\mathrm{sc}}=0 ;-1<$ RCA $2<0$ points to comparative disadvantages; when $\mathrm{RCA} 2=0$, export is equal to import, i.e. then $\mathrm{e}_{\mathrm{sc}}=i_{s c} ; 0$ $<$ RCA $2<1$ indicates the existence of comparative advantage; and when RCA2 $=1$, this means that import does not exist, i.e. $i_{s c}=0$.

MI shows the degree of specialization or lack of specialization in certain commodity groups. The calculation of the index is carried out at two levels, sectoral (S-MI) and national (N-MI):

$$
M I=\frac{e_{\mathrm{sc}}}{\sum_{\mathrm{s}=1}^{\mathrm{n}} E_{\mathrm{c}}}-\frac{i_{\mathrm{sc}}}{\sum_{\mathrm{s}=1}^{\mathrm{n}} I_{\mathrm{c}}}
$$

The value of MI indicator ranges from -1 to 1, i.e. $0<\mathrm{MI}<1$ points to a certain degree of country specialization in the commodity group, while $-1<\mathrm{MI}<0$ points to insufficient specialization of the country in the commodity group.

CTB is adjusted to determine the competitiveness of wood industry segments and is calculated on the basis of the formulas:

$$
\begin{aligned}
& N-C T B=\frac{e_{\mathrm{sc}}-i_{\mathrm{sc}}}{E_{\mathrm{c}}+I_{\mathrm{c}}}-\frac{E_{\mathrm{c}}-I_{\mathrm{c}}}{E_{\mathrm{c}}+I_{\mathrm{c}}} \cdot \frac{e_{\mathrm{sc}}+i_{\mathrm{sc}}}{E_{\mathrm{c}}+I_{\mathrm{c}}} \cdot 100 \\
& S-C T B=\frac{e_{\mathrm{sc}}-i_{\mathrm{sc}}}{E_{\mathrm{c}}+I_{\mathrm{c}}}-\frac{E_{\mathrm{c}}-I_{\mathrm{c}}}{E_{\mathrm{c}}+I_{\mathrm{c}}} \cdot \frac{e_{\mathrm{sc}}+i_{\mathrm{sc}}}{E_{\mathrm{c}}+I_{\mathrm{c}}} \cdot 100
\end{aligned}
$$

The left part of the equation represents the actual industry trade balance, weighted by its share in the total foreign trade exchange of the country that is crosssectoral trade. The right part of the equation measures the expected trade balance of the sector (commodity group), provided that each commodity contributes to the total trade balance according to its share in total trade. The difference between the actual and the expected trade balance measures a specific contribution to the total trade balance.

When it comes to CTB index, CTB $>0$ means that the actual surplus is higher than expected while the relative trade deficit is lower than expected, so that the sector makes a positive contribution to the overall trade balance; CTB $<0$ means that the sector makes a negative contribution to the overall trade balance, and that the actual results, compared with the expected, are negative or insufficient.

GLI measures export capacity at the macroeconomic level. For the assessment at the industry level, the index has been modified and its calculation shows the degree of commodity share in the inter-sectoral foreign trade of the country. The formula for calculating the GLI index is:

$$
G L I=1-\frac{\frac{e_{\mathrm{sc}}}{E_{\mathrm{c}}}-\frac{i_{\mathrm{sc}}}{I_{\mathrm{c}}}}{\frac{e_{\mathrm{sc}}}{E_{\mathrm{c}}}+\frac{i_{\mathrm{sc}}}{I_{\mathrm{c}}}}
$$

The GLI values range from 0 to $1(0<\mathrm{GLI}<1)$. Comparable value should be the GLI average for all sectors in the country or the GLI value at EU level or the global value of a given sector (commodity group).
The above mentioned indicators of trade competitiveness are only a suitable basis for further analysis of trade competitiveness. Therefore, MANOVA (Multivariate Analysis of Variance) with one factor of variability was applied, whereby the variability factor is the country. MANOVA is a method of statistical analysis, which is a multidimensional generalization of the ANOVA method. It is applied in order to test the equality of multidimensional random variables across multiple populations. The multidimensional random variable in this case is the trade competitiveness of the wood industry measured with 6 indicators (dimensions). The conclusion about the statistical significance of the difference between populations (countries) is based on the value of Wilks Lambda.

\subsection{Data set}

\subsection{Skup podataka}

The calculation of individual indicators is applied in the wood industry and its individual parts. What distinguishes the wood industry is the processing of raw wood and its further processing at different finalization stages. Accordingly, based on the United Nations Statistics Division - UNSTATS: Standard International Trade Classification (SITC Revision 3), wood industry [Wood industry $-24+63+821$ ] can be broken down into the following sections: $24-$ Cork and wood, 63 - Cork and wood manufactures (excluding furniture), and 821 - Furniture and parts.

Input data for assessing the competitiveness of wood industry and its parts for Serbia, Croatia, Romania, Bulgaria, and Bosnia \& Herzegovina in the period 2000-2015 was taken from the United Nations Conference on Trade and Development - UNCTAD: UNCTAD stat database: Merchandise trade matrix - detailed products, exports in thousands of dollars, annual, 1995-2015. Based on the selected database, the export and sector competitiveness of wood industry of the selected countries of South East Europe can be analyzed on the basis of data on the value of exports and imports of wood industry and its parts.

Statistical variables for measuring wood industry competitiveness were calculated by using the specially developed MS Excel application. A multivariate analysis of variance made in SPSS 20.0 software (Statistical Package for Social Sciences) was used for data analysis.

\section{RESULTS AND DISCUSSION}

\section{REZULTATI I RASPRAVA}

\subsection{Comparative analysis of wood industry competitiveness on the example of five countries of Southeast Europe in the period 2000-2015}

3.1. Komparativna analiza konkurentnosti drvne industrije na primjeru pet zemalja jugoistočne Europe u razdoblju 2000. - 2015.

The selection of competitiveness indicators was inspired by the effort to determine whether wood industry in the observed countries, as well as its individual parts, are competitive on the domestic and international markets. For this purpose, the paper analyzes 
Table 1 Average value of trade competitiveness indicators of selected countries of Southeast Europe in the period 2000-2015

Tablica 1. Prosječna vrijednost indikatora trgovinske konkurentnosti odabranih zemalja jugoistočne Europe u razdoblju 2000. -2015 .

\begin{tabular}{|l|c|c|c|c|c|c|}
\hline & RCA & RCA1 & RCA2 & MI & CTB & GLI \\
\hline Serbian wood industry / Drvna industrija Srbije & $\mathbf{0 . 6 7 1 9}$ & $\mathbf{2 . 2 5 2 5}$ & $\mathbf{0 . 0 1 5 4}$ & $\mathbf{0 . 0 1 9 8}$ & $\mathbf{0 . 8 4 1 9}$ & $\mathbf{0 . 6 7 8 3}$ \\
\hline Cork and wood / Pluto $i$ drvo & 0.5170 & 0.5786 & -0.0608 & 0.0046 & 0.2550 & 0.7496 \\
\hline Cork and wood manufactures / Proizvodi od pluta $i$ drva & 0.2817 & 0.6116 & -0.1675 & 0.0026 & 0.2764 & 0.8630 \\
\hline Furniture and parts / Namještaj $i$ dijelovi za namještaj & 1.0389 & 1.0322 & 0.1943 & 0.0117 & 0.3109 & 0.5246 \\
\hline Croatian wood industry / Drvna industrija Hrvatske & $\mathbf{0 . 9 6 0 6}$ & $\mathbf{4 . 2 5 5 6}$ & $\mathbf{0 . 1 5 1 0}$ & $\mathbf{0 . 0 4 6 3}$ & $\mathbf{1 . 4 0 7 0}$ & $\mathbf{0 . 5 5 6 6}$ \\
\hline Cork and wood / Pluto i drvo & 2.0435 & 1.9332 & 0.5880 & 0.0295 & 0.4590 & 0.2361 \\
\hline Cork and wood manufactures / Proizvodi od pluta i drva & 0.4786 & 0.7346 & -0.0840 & 0.0049 & 0.3095 & 0.7663 \\
\hline Furniture and parts / Namještaj i dijelovi za namještaj & 0.5505 & 1.5879 & -0.0489 & 0.0118 & 0.6385 & 0.7325 \\
\hline Romanian wood industry / Drvna industrija Rumunjske & $\mathbf{1 . 6 0 8 3}$ & $\mathbf{4 . 1 4 5 6}$ & $\mathbf{0 . 5 6 8 5}$ & $\mathbf{0 . 0 5 9 7}$ & $\mathbf{0 . 5 9 7 5}$ & $\mathbf{0 . 3 3 9 5}$ \\
\hline Cork and wood / Pluto i drvo & 2.9008 & 1.158 & 0.8314 & 0.0199 & 0.1425 & 0.1316 \\
\hline Cork and wood manufactures / Proizvodi od pluta i drva & 0.8635 & 0.914 & 0.2707 & 0.0092 & 0.1613 & 0.5993 \\
\hline Furniture and parts / Namještaj i dijelovi za namještaj & 1.7187 & 2.074 & 0.6055 & 0.0306 & 0.2937 & 0.3098 \\
\hline Bulgarian wood industry / Drvna industrija Bugarske & $\mathbf{0 . 9 6 9 2}$ & $\mathbf{1 . 6 5 4 2}$ & $\mathbf{0 . 3 1 1 8}$ & $\mathbf{0 . 0 1 8 2}$ & $\mathbf{0 . 3 0 0 7}$ & $\mathbf{0 . 5 5 7 5}$ \\
\hline Cork and wood / Pluto i drvo & 2.0425 & 0.3481 & 0.6841 & 0.0055 & 0.0498 & 0.2396 \\
\hline Cork and wood manufactures / Proizvodi od pluta i drva & 0.5162 & 0.4641 & 0.1017 & 0.0033 & 0.1033 & 0.7538 \\
\hline Furniture and parts / Namještaj i dijelovi za namještaj & 1.0039 & 0.8420 & 0.3278 & 0.0094 & 0.1477 & 0.5422 \\
\hline B\&H wood industry / Drvna industrija BiH & $\mathbf{1 . 7 8 7 5}$ & $\mathbf{8 . 6 0 4 4}$ & $\mathbf{0 . 4 2 1 8}$ & $\mathbf{0 . 1 3 0 2}$ & $\mathbf{2 . 6 2 0 7}$ & $\mathbf{0 . 2 8 8 4}$ \\
\hline Cork and wood / Pluto i drvo & 3.3771 & 4.3490 & 0.8384 & 0.0779 & 1.0435 & 0.0769 \\
\hline Cork and wood manufactures / Proizvodi od pluta i drva & 0.5296 & 0.9373 & -0.1693 & 0.0069 & 0.4748 & 0.7420 \\
\hline Furniture and parts / Namještaj i dijelovi za namještaj & 1.5112 & 3.3182 & 0.2889 & 0.0454 & 1.1024 & 0.3697 \\
\hline A
\end{tabular}

Authors' calculation, based on data taken from the UNCTADstat database / Izračun autora na temelju podataka iz baze podataka UNCTADstat

trade competitiveness of wood industry and its parts based on different modifications of RCA, CTB, GLI, and MI coefficients. The obtained results of individual indicators are given in Table 1.

The positive average value of the RCA index indicates that the wood industry of the observed countries as a whole, as well as its individual parts (Cork and wood, Cork and wood manufactures excluding furniture, and Furniture and parts), have a comparative advantage on the national market. The wood industries of Romania and Bosnia \& Herzegovina have built significant competitiveness at the international level. The wood industries of Croatia and Bulgaria are becoming internationally competitive, while the wood industry of Serbia is not sufficiently competitive on the international market.

Within wood industry, the highest value of the RCA index, in the field of Cork and wood, is found in companies from Bosnia \& Herzegovina. They have a significant level of international competitiveness, and they are followed by companies from Romania, Croatia, and Bulgaria. With Cork and wood manufactures excluding furniture, the situation is significantly different because companies of none of the five countries achieve competitiveness at the international level, but only a certain level of competitiveness within the national economy. The biggest competitors are companies from Romania, followed by companies from Bosnia \& Herzegovina and Bulgaria, and the lowest level of competitiveness is found in wood processing companies from Croatia and Serbia. When it comes to Furniture and parts, the situation is significantly more favorable in most of the countries observed. The most competitive Furniture and parts manufacturers are from Romania and Bosnia \& Herzegovina, who manage to reach a certain level of international competitiveness, while Furniture and parts manufacturers from Serbia and Bulgaria are on the right track to achieve international competitiveness. The least favorable situation is with Furniture \& parts manufacturers from Croatia because they are only competitive within the domestic market.

The average value of the RCA1 index shows that, in all countries observed, there is revealed comparative advantage of wood industry on the global market, with wood industry of Bosnia \& Herzegovina having the highest comparative advantage, followed by wood industry of Croatia and Romania, while the lowest comparative advantage is found in wood industry of Serbia and Bulgaria. Analysis of individual parts of wood industry shows that Cork and wood companies from Bulgaria and Serbia, Cork and wood manufactures excluding furniture companies from Bulgaria, Serbia, Croatia, Romania, and Bosnia \& Herzegovina, as well as Furniture \& parts manufacturers from Bulgaria do not have competing advantage on the relevant market.

The obtained results show that Cork and wood companies from Bulgaria and Serbia, Cork and wood manufactures excluding furniture companies from Bulgaria, Serbia, Croatia, Romania, and Bosnia \& Herzegovina, as well as Furniture and parts manufacturers from Bulgaria do not have a competitive advantage on the international market. It follows that the hypothesis $\mathrm{H} 1$ is confirmed in the part related to competitiveness of observed countries wood industry on the domestic market. On the contrary, the results do not confirm the 
second part of the hypothesis $\mathrm{H} 1$, which refers to trade competitiveness of all parts of wood industry of these countries.

The analysis of the average value of the RCA2 index shows the existence of a positive contribution of wood industry in the formation of active trade balance in all countries observed. The largest wood industry surplus is recorded in Romania, Bosnia \& Herzegovina, and Bulgaria, and to a lesser extent in Croatia, while this contribution is the smallest in Serbia. Great positive contribution to foreign trade also comes from individual parts of wood industry, especially Cork and wood companies from Bosnia \& Herzegovina, Romania, Bulgaria, and Croatia, as well as Furniture and parts manufacturers from Croatia, and to a lesser extent Cork and wood manufactures excluding furniture from Romania and Bulgaria, as well as Furniture and parts manufacturers from Bulgaria, Bosnia \& Herzegovina, and Serbia. Unlike these companies, Cork and wood companies from Serbia, as well as Cork and wood manufactures excluding furniture from Serbia, Croatia, and Bosnia \& Herzegovina and Furniture \& parts manufacturers from Croatia, due to comparative disadvantages, record a deficit in foreign trade operations, thereby adversely affecting foreign trade balance trends.

The average MI values indicate that all countries observed achieve a certain degree of wood industry specialization. The highest level of wood industry specialization is achieved in Bosnia \& Herzegovina and Romania, and the lowest in Bulgaria and Serbia. In relation to certain parts of wood industry, Cork and wood manufactures excluding furniture companies record the lowest specialization in all countries observed. In Serbia, Romania, and Bulgaria, Furniture and Parts manufacturers have a higher degree of specialization in relation to Cork and wood companies, unlike Bosnia \& Herzegovina and Croatia, where there is greater specialization in the field of Cork and wood than Furniture and parts.

The obtained CTB values show that in all countries observed wood industry creates a higher surplus than expected and that the actual trade balance is better than expected, so that wood industry sector contributes positively to the overall trade balance. This contribution is particularly high in Bosnia \& Herzegovina and Croatia and least pronounced in Bulgaria and Romania, while Serbia is at the level of the average countries observed. An identical situation is found when the analysis goes down to the level of Cork and wood and Cork and wood manufactures excluding furniture, as well as Furniture and parts companies.

The obtained GLI values show that the capacity to use the economies of scale in the wood industry is mostly used by companies from Serbia, then Bulgaria and Croatia, and the least in companies from Bosnia \& Herzegovina and Romania. An almost identical situation is found with companies operating in the Cork and wood area. A somewhat different situation is found with Cork and wood manufactures excluding furniture companies, since, in addition to Serbia, companies from Croatia and Bulgaria widely use economies of scale, and to a lesser extent companies from Romania and Bosnia \& Herzegovina. Furniture \& parts manufacturers, mostly using economies of scale, come from Croatia, Bulgaria, and Serbia, and companies from Romania and Bosnia \& Herzegovina use it the least.

\subsection{Multivariate analysis of variance of wood industry trade competitiveness on the example of five countries of Southeast Europe} in the period 2000-2015

3.2. Multivarijantna analiza varijance trgovinske konkurentnosti drvne industrije na primjeru pet zemalja jugoistočne Europe u razdoblju 2000. 2015.

The question that arises here is whether there is a statistically significant difference in terms of the level of wood industry competitiveness among the countries observed. Data in Table 2 (Wilks' Lambda) gives a positive answer to this question. By combining the values of six competitiveness indicators, the WL value obtained is less than 0.05 , which proves the existence of a statistically significant difference between the achieved competitiveness levels of the analyzed Southeast European countries, thus confirming the H2 hypothesis.

Table 3 gives more detailed information on competitiveness indicators exhibiting a difference (column Sig.). Data points to the conclusion that the values of all observed indicators are statistically different depending on individual countries. What is more, the table (Partial Eta Squared column) indicates that the highest variance in the degree of competitiveness, produced as a result of the country included in the analysis, is present with RCA1, and the lowest with RCA2 (absolute values in this column are compared), and it

Table 2 Multivariate Tests

Tablica 2. Multivarijantni testovi

\begin{tabular}{|l|l|c|c|c|c|c|c|}
\hline $\begin{array}{l}\text { Effect } \\
\text { Učinak }\end{array}$ & $\begin{array}{c}\text { Value } \\
\text { Vrijednost }\end{array}$ & $\boldsymbol{F}$ & $\begin{array}{c}\text { Hypothesis df } \\
\text { Hipoteze df }\end{array}$ & $\begin{array}{c}\text { Error df } \\
\text { Pogreška df }\end{array}$ & $\begin{array}{c}\text { Significance } \\
\text { Značajnost }\end{array}$ & $\begin{array}{c}\text { Partial Eta Squared } \\
\text { Djelomični eta } \\
\text { kvadrat }\end{array}$ \\
\hline \multirow{3}{*}{$\begin{array}{l}\text { Intercept } \\
\text { Odjel }\end{array}$} & Pillai's Trace & 1.000 & $43003.352^{\mathrm{b}}$ & 6.000 & 95.000 & .000 & 1.000 \\
\cline { 2 - 8 } & Wilks' Lambda & .000 & $43003.352^{\mathrm{b}}$ & 6.000 & 95.000 & .000 & 1.000 \\
\cline { 2 - 8 } & Hotelling's Trace & 2716.001 & $43003.352^{\mathrm{b}}$ & 6.000 & 95.000 & .000 & 1.000 \\
\cline { 2 - 8 } & Roy's Largest Root & 2716.001 & $43003.352^{\mathrm{b}}$ & 6.000 & 95.000 & .000 & 1.000 \\
\hline \multirow{3}{*}{$\begin{array}{l}\text { Country } \\
\text { Zemlja }\end{array}$} & Pillai's Trace & 1.851 & 14.071 & 24.000 & 392.000 & .000 & .463 \\
\cline { 2 - 8 } & Wilks' Lambda & .020 & 28.904 & 24.000 & 332.625 & .000 & .626 \\
\cline { 2 - 8 } & Hotelling's Trace & 14.473 & 56.384 & 24.000 & 374.000 & .000 & .783 \\
\cline { 2 - 8 } & Roy's Largest Root & 12.320 & $201.234^{\mathrm{c}}$ & 6.000 & 98.000 & .000 & .925 \\
\hline
\end{tabular}


Table 3 Multivariate analysis of variance

Tablica 3. Multivarijantna analiza varijance

\begin{tabular}{|c|c|c|c|c|c|c|c|c|c|}
\hline \multirow{2}{*}{$\begin{array}{l}\text { Indicator } \\
\text { Pokazatelj }\end{array}$} & \multicolumn{5}{|c|}{$\begin{array}{l}\text { Country } \\
\text { Zemlja }\end{array}$} & \multirow{2}{*}{$\mathbf{F}$} & \multirow{2}{*}{$\underset{p \text {-vrijednost }}{p \text {-value }}$} & \multirow{2}{*}{$\begin{array}{l}\text { Partial Eta } \\
\text { Squared } \\
\text { Djelomični } \\
\text { eta kvadrat }\end{array}$} & \multirow{2}{*}{ Bonferroni } \\
\hline & $\begin{array}{c}1 \\
\text { SRB }\end{array}$ & $\begin{array}{c}2 \\
\text { HR }\end{array}$ & $\begin{array}{c}3 \\
\text { ROM }\end{array}$ & $\begin{array}{c}4 \\
\text { BUG }\end{array}$ & $\begin{array}{c}5 \\
\mathrm{BiH}\end{array}$ & & & & \\
\hline $\mathrm{RCA}$ & 0.722 & 0.998 & 1.773 & 1.047 & 1.837 & 69.407 & .000 & .735 & $\begin{array}{l}1-2,1-3,1-4,1-5 \\
2-3,2-5,3-4,4-5\end{array}$ \\
\hline RCA1 & 2.482 & 4.111 & 4.219 & 1.562 & 9.377 & 189.771 & .000 & .884 & $\begin{array}{c}1-2,1-3,1-4,1-5 \\
2-4,2-5,3-4,3-5,4-5\end{array}$ \\
\hline RCA2 & 0.047 & 0.175 & 0.615 & 0.364 & 0.364 & 43.866 & .000 & .637 & $\begin{array}{l}1-3,1-4,1-5,2-3, \\
2-4,2-5,3-4,3-5\end{array}$ \\
\hline MI & 0.025 & 0.048 & 0.066 & 0.019 & 0.151 & 92.870 & .000 & .788 & $\begin{array}{c}1-2,1-3,1-5,2-4,2-5,3- \\
4,3-5,4-5\end{array}$ \\
\hline СТВ & 0.936 & 1.388 & 0.625 & 0.257 & 3.199 & 51.032 & .000 & .671 & $\begin{array}{c}1-4,1-5,2-3,2-4,2-5,3- \\
5,4-5\end{array}$ \\
\hline GLI & 0.657 & 0.542 & 0.302 & 0.528 & 0.28 & 68.671 & .000 & ,733 & $\begin{array}{l}1-2,1-3,1-4,1-5, \\
2-3,2-5,3-4,4-5\end{array}$ \\
\hline
\end{tabular}

can be concluded that the largest variations are found with RCA and RCA1 indicators.

Information on which countries are statistically different in terms of individual quality dimensions is found in the Bonferroni column in Table 3. For example, there is a statistically significant difference between Serbia (1) and all other countries in terms of the value of RCA indicator, but there is no statistically significant difference between Croatia (2) and Bulgaria
(4) regarding the value of RCA indicator, as there are no differences between Romania (3) and B\&H (5).

When looking at RCA1 indicator, there is no significant difference between Croatia and Romania only (2-3). With RCA2 indicator, the difference is not significant between Serbia and Croatia (1-2), or Bulgaria and Bosnia \& Herzegovina (4-5). According to MI indicator, there is no significant difference between Serbia and Bulgaria (1-4), or between Croatia and Roma-

Table 4 Competitiveness of countries depending on the finalization stage

Tablica 4. Konkurentnost zemalja u ovisnosti o stupnju finalizacije

\begin{tabular}{|c|c|c|c|c|c|c|}
\hline & \multirow{2}{*}{$\begin{array}{l}\text { Mean } \\
\text { Srednja } \\
\text { vrijed- } \\
\text { nost }\end{array}$} & \multirow{2}{*}{$\begin{array}{c}\text { Std. } \\
\text { Devia- } \\
\text { tion } \\
\text { Stand. } \\
\text { devi- } \\
\text { jacija }\end{array}$} & \multirow{2}{*}{$\begin{array}{l}\text { Std. Error } \\
\text { Stand. } \\
\text { pogreška }\end{array}$} & \multicolumn{2}{|c|}{$\begin{array}{c}95 \% \text { Confidence } \\
\text { Interval for Mean } \\
95 \% \text {-tni interval } \\
\text { pouzdanosti }\end{array}$} \\
\hline & & & & & $\begin{array}{c}\text { Lower } \\
\text { Bound } \\
\text { Donja } \\
\text { granica }\end{array}$ & $\begin{array}{l}\text { Upper } \\
\text { Bound } \\
\text { Gornja } \\
\text { granica }\end{array}$ \\
\hline \multirow{4}{*}{ RCA } & Cork and wood / pluto i drvo & 2.17640 & 1.090346 & .487618 & .82256 & 3.53024 \\
\hline & Cork and wood manufactures / proizvodi od pluta i drva & .53420 & .209624 & .093747 & .27392 & .79448 \\
\hline & Furniture and parts / namještaj i dijelovi za namještaj & 1.16480 & .459735 & .205600 & .59396 & 1.73564 \\
\hline & Total / ukupno & 1.29180 & .950174 & .245334 & .76561 & 1.81799 \\
\hline \multirow{4}{*}{ RCA1 } & Cork and wood / pluto i drvo & 1.67340 & 1.616034 & .722712 & -.33317 & 3.67997 \\
\hline & Cork and wood manufactures / proizvodi od pluta i drva & .73240 & .200861 & .089828 & .48300 & .98180 \\
\hline & Furniture and parts / namještaj i dijelovi za namještaj & 1.77080 & .990917 & .443152 & .54041 & 3.00119 \\
\hline & Total / ukupno & 1.39220 & 1.128338 & .291336 & .76735 & 2.01705 \\
\hline \multirow{4}{*}{ RCA2 } & Cork and wood / pluto i drvo & .57600 & .371230 & .166019 & .11506 & 1.03694 \\
\hline & Cork and wood manufactures / proizvodi od pluta i drva & -.00940 & .191644 & .085706 & -.24736 & .22856 \\
\hline & Furniture and parts / namještaj i dijelovi za namještaj & .27360 & .236692 & .105852 & -.02029 & .56749 \\
\hline & Total / ukupno & .28007 & .356500 & .092048 & .08264 & .47749 \\
\hline \multirow{4}{*}{ MI } & Cork and wood / pluto i drvo & .02756 & .029967 & .013402 & -.00965 & .06477 \\
\hline & Cork and wood manufactures / proizvodi od pluta $i$ drva & .00546 & .002602 & .001164 & .00223 & .00869 \\
\hline & Furniture and parts / namještaj i dijelovi za namještaj & .02184 & .015686 & .007015 & .00236 & .04132 \\
\hline & Total / ukupno & .01829 & .020562 & .005309 & .00690 & .02967 \\
\hline \multirow{4}{*}{ CTB } & Cork and wood / pluto i drvo & .39020 & .396015 & .177103 & -.10152 & .88192 \\
\hline & Cork and wood manufactures / proizvodi od pluta i drva & .26480 & .144237 & .064505 & .08571 & .44389 \\
\hline & Furniture and parts / namještaj i dijelovi za namještaj & .49860 & .381936 & .170807 & .02436 & .97284 \\
\hline & Total / ukupno & .38453 & .319701 & .082546 & .20749 & .56158 \\
\hline \multirow{4}{*}{ GLI } & Cork and wood / pluto i drvo & .28700 & .268004 & .119855 & -.04577 & .61977 \\
\hline & Cork and wood manufactures / proizvodi od pluta $i$ drva & .74480 & .094566 & .042291 & .62738 & .86222 \\
\hline & Furniture and parts / namještaj i dijelovi za namještaj & .49600 & .165528 & .074026 & .29047 & .70153 \\
\hline & Total / ukupno & .50927 & .261581 & .067540 & .36441 & .65413 \\
\hline
\end{tabular}


...... Cvetanović, Nikolić, Cvetanović: Wood Industry Trade Competitiveness of Selected...

Table 5 ANOVA

Tablica 5. ANOVA test

\begin{tabular}{|c|c|c|c|c|c|c|}
\hline & & $\begin{array}{c}\text { Sum of Squares } \\
\text { Zbroj kvadrata }\end{array}$ & $D f$ & \begin{tabular}{|c|} 
Mean Square \\
Kvadrat srednje \\
vrijednosti
\end{tabular} & $\boldsymbol{F}$ & Sig. \\
\hline \multirow{3}{*}{ RCA } & Between groups / između grupa & 6.863 & 2 & 3.432 & 7.128 & .009 \\
\hline & Within groups / unutar grupa & 5.777 & 12 & .481 & & \\
\hline & Total / ukupno & 12.640 & 14 & & & \\
\hline \multirow{3}{*}{ RCA1 } & Between groups / između grupa & 3.289 & 2 & 1.644 & 1.358 & .294 \\
\hline & Within groups / unutar grupa & 14.535 & 12 & 1.211 & & \\
\hline & Total / ukupno & 17.824 & 14 & & & \\
\hline \multirow{3}{*}{ RCA2 } & Between groups / između grupa & .857 & 2 & .429 & 5.576 & .019 \\
\hline & Within groups / unutar grupa & .922 & 12 & .077 & & \\
\hline & Total / ukupno & 1.779 & 14 & & & \\
\hline \multirow{3}{*}{ MI } & Between groups / između grupa & .001 & 2 & .001 & 1.715 & .221 \\
\hline & Within groups / unutar grupa & .005 & 12 & .000 & & \\
\hline & Total / ukupno & .006 & 14 & & & \\
\hline \multirow{3}{*}{ СТВ } & Between groups / između grupa & .137 & 2 & .068 & .635 & .547 \\
\hline & Within groups / unutar grupa & 1.294 & 12 & .108 & & \\
\hline & Total / ukupno & 1.431 & 14 & & & \\
\hline \multirow{3}{*}{ GLI } & Between groups / između grupa & .525 & 2 & .263 & 7.284 & .008 \\
\hline & Within groups / unutar grupa & .433 & 12 & .036 & & \\
\hline & Total / ukupno & .958 & 14 & & & \\
\hline
\end{tabular}

nia (2-3). The average value of CTB indicator in Serbia does not differ significantly from the value of this indicator in Croatia and Romania (1-2 and 1-3). In addition, according to this indicator, there is no significant difference between Romania and Bulgaria (3-4). According to GLI indicator, Croatia and Bulgaria (2-4) do not significantly differ, nor do Romania and Bosnia \& Herzegovina (3-5).

Data on the values of these indicators is found in the Countries column (with appropriate sub-columns denoting countries), so it is still possible to compare which of the countries has the highest value of this competitiveness indicator and which the lowest. In the observed period, Bosnia \& Herzegovina has the highest indicators of RCA, RCA1, RCA2 (together with Bulgaria), MI, and CTB, while the highest value of GLI indicator relates to Serbia.

In order to prove the $\mathrm{H} 3$ hypothesis, the values of the competitiveness indicators are examined according to the finalization stage, with all countries considered as a whole (Table 4).

According to the results of Table 4, the highest average value of RCA, RCA2, and MI indicators is at the lowest finalization stage - Cork and wood. The highest average value of GLI indicator is related to a higher finalization stage, i.e. Cork and wood manufactures excluding furniture, while the highest average value of RCA1 and CTB in the countries observed is achieved at the highest finalization stage - Furniture and parts.

Table 5 gives the results of testing the significance of the difference in the average values of indicators among different finalization stages. The finalization stages are observed as a factor of variability. Based on the results, it can be concluded that the difference in the average value of indicators between the finalization stages is significant with RCA, RCA2, and GLI indicators (Sig. is less than 0.05 ), while with other indicators of competitiveness there is no significant difference in the average values between different finalization stages.

Based on the results shown in Tables 4 and 5, it can be concluded that, if only RCA1 and CTB indicators are observed, the wood processing stage has a positive impact on trade competitiveness, but this impact is not statistically significant. According to other indicators, the finalization stage has no positive impact on trade competitiveness, i.e. hypothesis $\mathrm{H} 3$ cannot be confirmed.

\subsection{Overall discussion}

3.3. Rasprava

Numerous studies deal with wood industry trade competitiveness in individual countries. For example, Carvalho et al. (2009) use RCA and data on relative market share on a global scale to come to the conclusion on high competitiveness of Brazilian wood pulp processing on the international market. Dieter \& Englert (2007) explore the competitiveness of certain parts of the wood-processing industry on a global scale, with emphasis on the wood processing industry of Germany, through revealed comparative advantage and constant market share indices, to conclude that Russia is most competitive with untreated timber, Finland with secondary treated wood, and Poland with final wood production. Mäkelä (2009) studies the competitiveness of the wood processing industry in Russia, and concludes that it is competitive on the international market only in the production of low value added products. In the paper Evaluating the Competitiveness of Wood Processing Industry, Sujová et al. (2015a) analyze competitiveness of Czech and Slovak wood industries in relation to the EU wood processing industry taken as a whole in the period 2003-2012. The authors come to the conclusion that competitiveness of the Czech wood industry is low compared to the EU wood 
industry, while wood industry of Slovakia is on its way to losing its competitiveness in the coming period. Identical results are obtained for wood processing and furniture production. The authors conclude that the success of the wood industry lies in actively finding new comparative advantage, since competitive advantage based on prices and costs obviously disappears. Authors Sujová and Hlaváčková (2015) have come to the identical result in evaluating the level and development of competitiveness of WPI in the Czech Republic in sub-sectoral structure for the period 2003-2012. Paluš et al. (2015) analyzes the competitiveness of the wood processing industry in Hungary, Poland, Slovakia, and the Czech Republic, using indicators related to trade specialization, ratio of exports and imports, standard Grubel-Lloyd index, revealed comparative advantage and the change of competitiveness in the period from 2003-2012. Their conclusion is that within the group of analyzed countries, Slovakia shows a comparative advantage in most products, especially in the trade of primarily processed wood, wood-based panels, pulp, paper, and cardboard products. The results of the analysis also show that specialization within the industry increases the level of added value.

The results of the analysis carried out in this paper confirm the hypothesis $\mathrm{H} 1$ in the part of wood industry competitiveness of the observed countries in the domestic market. On the contrary, the results do not confirm the second part of the hypothesis H1 that relates to the export competitiveness of all parts of the wood industry of the countries observed. Also, the results of the study showed the existence of statistically significant differences between the achieved levels of competitiveness of the annihilated countries, which confirmed the hypothesis H2. The research also showed that the level of finalization of the wood industry in the work of the countries involved does not have a positive impact on export competitiveness, which means that H3 hypotheses cannot be confirmed. Overall, the results of the research in this paper largely correspond to the results obtained in the aforementioned, comparable, foreign studies. As the survey analyzes the countries of South East Europe with a relatively low degree of specialization in the wood industry, logically the degree of finalization has little impact on their commercial competitiveness. The results of comparable studies show that specialization within the wood industry significantly affects the increase in the added value level only in countries that have achieved a significant degree of specialization. This implies that the countries of South East Europe, in view of increasing the commercial competitiveness of wood industry, or increasing the size of revenues within the business, must significantly raise the level of specialization within the wood industry, so as to increase its overall effect. The current situation suggests that the observed countries of South-Eastern Europe have a subsidiary role within the global value chain of the wood industry and that unless they change, the existing business and development models will be condemned to stagnation and/or decline in the long term on a more demanding and challenging global market.

\section{CONCLUSIONS \\ 4. ZAKLJUČAK}

Based on the results of the previous analysis, it can be concluded that wood industry has a large export potential in the economy, with a significant share in manufacturing industry in the selected Southeast Europe countries. This is important since it is an activity that does not depend on imported raw materials as timber assortment in these countries is large enough within the national economy.

The obtained results show that wood industry companies in the selected countries, taken as a whole, achieve a competitive position on the national market, but this cannot be said for international competitiveness of these countries. To be specific, Cork and wood companies from Bulgaria and Serbia, Cork and wood manufactures excluding furniture companies from Bulgaria, Serbia, and Croatia, as well as Furniture \& parts manufacturers from Bulgaria do not have a competitive advantage on the international market.

By combining the values of six competitiveness indicators, the WL value of less than 0.05 is obtained, which proves the existence of a statistically significant difference between the achieved level of competitiveness of Croatia, Serbia, Romania, and Bosnia \& Herzegovina in the period 2000-2015.

Judging by RCA1 and CTB indicators, it can be concluded that the wood processing stage has a positive impact on export competitiveness; however, this impact is not statistically significant. According to other indicators, the wood processing stage has no positive impact on export competitiveness.

\section{REFERENCES}

\section{LITERATURA}

1. Balassa, B., 1965: Trade liberalisation and "revealed" comparative advantage. The manchester school, 33(2): 99123. https://doi.org/10.1111/j.1467-9957.1965.tb00050.x.

2. Carvalho, K.; Silva, M.; Soares, N., 2009: Competitiveness of Brazilian Wood Pulp in the International Market. CERNE, 15 (4): 383-390.

3. Cvetanović, S.; Filipović, M.; Nikolić, M.; Belović, D., 2015: Endogenous growth theory and regional development policy. Spatium, 34: 10-17. https://doi.org/10.2298/SPAT1534010C.

4. Cvetković, M.; Petrović-Ranđelović, M., 2017: The Analysis of Agricultural Products Export Competitiveness of the Republic of Serbia based on the RCA Index. Economic Themes, 55(3): 399-420.

https://doi.org/10.1515/ethemes-2017-0022.

5. Dieter, M.; Englert, H., 2007: Competitiveness in the global forest industry sector: an empirical study with special emphasis on Germany. European Journal of Forest Research, 126(3): 401-412. https://doi.org/10.1007/s10342-006-0159-x.

6. Fagerberg, J.; Srholec, M.; Knell, M., 2007: The Competitiveness of Nations: Why Some Countries Prosper While Others Fall Behind? World Development, 35: 1595-1620. https://doi.org/10.1016/j.worlddev.2007.01.004. 
7. Garelli, S., 2004: Competitiveness of Nations: The Fundamental. IMD World Competitiveness Yearbook 2004, Lausanne, Switzerland, pp. 730-74.

8. Grubel, H.; Lloyd, P., 1971: The Empirical Measurement of Intra-Industry Trade. Economic Record, 47 (120): 494517. https://doi.org/10.1111/j.1475-4932.1971.tb00772.x.

9. Han, X.; Wen, Y.; Kant, S., 2009: The global competitiveness of the Chinese wooden furniture industry. Forest Policy and Economics, 11(8): 561-569. https://doi.org/10.1016/j.forpol.2009.07.006.

10. Hatzichronoglou, T., 1996: Globalization and Competitiveness: relevant indicators, OECD. https://doi.org/10.1787/885511061376.

11. Jovović, D., 2017: Improving regional competitiveness in the light growth theory recommendations. Economic Themes, 55(3): 319-333. https://doi.org/10.1515/ethemes-2017-0018.

12. Kitson, M.; Martin, R.; Tyler, P., 2004: Regional competitiveness: an elusive yet key concept? Regional studies, 38(9): 991-999. https://doi.org/10.1080/0034340042000320816.

13. Lall, S., 2001: Competitiveness, Technology and Skills. Edward Elgar Publishing. https://doi.org/10.4337/9781781950555.

14. Mäkelä, T., 2009: The Russian Forest Industry: A Case Of Competitiveness And Export Taxes, epub.lib.aalto.fi /fi /ethesis/pdf/12057/hse_ethesis_12057.pdf (Accessed August 07, 2017).

15. Melišek, I., 2012: Meranie a hodnotenie makroekonomických výsledkov zahraničného obchodu. Ekonomické rozhl'ady, 41(4): 439-451.

16. Michaely, M., 1962: Multilateral balancing in international trade. The American Economic Review, 52(4): 685-702.

17. Paluš, H.; Parobek, J.; Liker, B., 2015: Trade Performance and Competitiveness of the Slovak Wood Processing Industry within the Visegrad Group Countries. Drvna industrija 66 (3): 195-203.

https://doi.org/10.5552/drind.2015.1431.

18. Rybakovas, E., 2009: Competitiveness of Lithuanian manufacturing industry. Economics and management, 14: 912-918.

19. Siggel, E., 2006: International Competitiveness and Comparative Advantage: A Survey and a Proposal for Measurement. Journal of Industry, Competition and Trade, 6(2): 137-159. https://doi.org/10.1007/s10842-006-8430-x.

20. Sujová, A.; Hlaváčková, P., 2015: Sectoral Analysis of Competitiveness of Wood Processing Industry in the
Czech Republic. Acta Universitatis Agriculturae et Silviculturae Mendelianae Brunensis, 63(1): 293-302. http://dx.doi.org/10.11118/actaun201563010293.

21. Sujová, A.; Hlaváčková, P.; Marcineková, K., 2015a: Evaluating the Competitiveness of Wood Processing Industry. Drvna industrija, 66(4): 281-288. https://doi.org/10.5552/drind.2015.1432.

22. Sujová, A.; Hlaváčková, P.; Marcineková, K., 2015b: The Trade Competitiveness of Furniture Products. Drewno, 58(195): 103-117. doi: 10.12841/wood.1644-3985.104.09.

23. Toming, K., 2007: The Impact of EU Accession on the Export Competitiveness of the Estonian Food Processing Industry. Post-Communist Economies, 19(2): 187-207. https://doi.org/10.2139/ssrn.959212.

24. UNIDO - The United Nations Industrial Development Organization, 2002: Competing through innovation and learning. Industrial Development Report 2002/2003, Vienna. https://doi.org/10.18356/94674506-en.

25. UNIDO - The United Nations Industrial Development Organization, 2013: The Industrial Competitiveness of Nations: Looking Back, Forging Ahead. Competitive Industrial Performance Report 2012/2013, Vienna.

26. ***World bank: Trade Indicators - World Integrated Trade Solution (WITS). http://wits.worldbank.org/ WITS/WITS/WITSHELP/Content/Utilities/e1.trade_indicators.htm_(Accessed July 13, 2017).

27. $* * *$ United Nations Conference on Trade and Development - UNCTAD: UNCTADstat database: Merchandise trade matrix - detailed products, exports in thousands of dollars, annual, 1995 - 2015, http://unctadstat.unctad. org/wds/TableViewer/tableView.aspx?ReportId=24738 (Accessed July 12, 2017).

28. *** United Nations Statistics Division - UNSTATS: Standard International Trade Classification - SITC Revision 3. https://unstats.un.org/unsd/cr/registry/regcst. asp?Cl=14 (Accessed August 23, 2017).

\section{Corresponding address:}

Prof. SLOBODAN CVETANOVIĆ, Ph.D.

University of Nis, Faculty of Economics

Trg kralja Aleksandra Ujedinitelja 11

18105 Niš, SERBIA

e-mail: slobodan.cvetanovic@eknfak.ni.ac.rs 